\title{
Effect of Contact Pesticides on Vine Mealybug Parasitoids, Anagyrus sp. near pseudococci (Girault) and Coccidoxenoides perminutus (Timberlake) (Hymenoptera: Encyrtidae)
}

\author{
N. Mgocheki* and P. Addison \\ Department of Conservation Ecology and Entomology, Faculty of AgriSciences, \\ Stellenbosch University, Private Bag X1, Matieland, 7602, South Africa
}

Submitted for publication: June 2009

Accepted for publication: August 2009

Key words: Bioassay, biological control, mortality, toxicity

\begin{abstract}
Anagyrus species near pseudococci (Girault) and Coccidoxenoides perminutus (Timberlake) (Hymenoptera: Encyrtidae) are well-known mealybug parasitoids. Both are proven biological control agents of Planococcus ficus (Signoret) (Hemiptera: Pseudococcidae) in vineyards. These parasitoids are affected by some pesticides used for the control of ants (Hymenoptera: Formicidae) and $P$. ficus in vineyards. To establish which of the vineyard pesticides is more toxic to parasitoids, pesticide bioassays were carried in the laboratory using adult and pupal parasitoids. Fipronil and $\alpha$-cypermethrin caused significant acute toxicity of both parasitoids. Low mortality was recorded for all these pesticides for parasitoids emerging from mummies indicating that the mummy case was an effective barrier to pesticides for parasitoids. Buprofezin, mancozeb and an insecticidal soap were not toxic to parasitoids in both bioassays. Some pesticides have far-reaching negative impacts on parasitoids of orchard and vineyard arthropod pests. A refinement on pest management strategies regarding method and timing of application of pesticides where parasitoids constitute part of the pest management program is essential.
\end{abstract}

Use of pesticides in integrated pest management (IPM) depends in part, on knowledge of the effects of pesticides on beneficial insects like natural enemies and pollinators. The knowledge allows the use of strategies that minimise the disruptive effect of pesticides, such as use of selective compounds and reduced rates or proper timing of applications (Hassan et al., 1994; Williams \& Price, 2004). Direct impacts of pesticides due to direct contact with toxins are manifested as short-term mortality or relatively long term sublethal effects, which generally have the greatest impact on natural enemies' life span, fecundity and ability to locate hosts (Desneux et al., 2007).

Anagyrus species near pseudococci (Girault) and Coccidoxenoides perminutus (Timberlake) (Hymenoptera: Encyrtidae) are tiny solitary koinobiont endoparasitoids of the vine mealybug, Planococcus ficus (Signoret) (Hemiptera: Pseudococcidae) (Islam $\&$ Copland, 1997). These parasitoids have potential for use in augmentative release programs for suppression of vine mealybug in Western Cape Province vineyards (Whitehead, 1957; Walton $\&$ Pringle, 1999). Effective use of $A$. sp. near pseudococci and C. perminutus in the augmentative release programs will depend on timing parasitoid releases so that the disruptive effects of pesticides are minimised. Previous researchers noted a negative effect on parasitoid performance of mass released $C$. perminutus in Western Cape Province vineyards due to injudicious application of pesticides during release periods (Walton \& Pringle, 1999). Because releases of parasitoids are made after pesticide applications, an understanding of the direct effects of pesticide residues on these two parasitoids is critical for the development of appropriate guidelines for timing of releases.
Work has been done on impacts of field weathered pesticides residues on Aphelinus mali Haldeman, a parasitoid of wooly apple aphid, Eriosoma lanigerum (Hausmann) in apple orchards (Heunis \& Pringle, 2003) and in citrus orchards on C. perminutus (formerly Pauridia peregrine Timb) (St. Leger Searle, 1963; Hattingh \& Tate, 1995). There is limited information on impacts of pesticides on parasitoids in vineyards yet some, like chlorpyrifos, fipronil, $\alpha$-cypermethrin, among others, are used against vine mealybugs and ants.

Several pesticides were found compatible with natural enemies in apple and citrus orchards in South Africa (Wakgari \& Giliomee 2001; Heunis \& Pringle 2003). Very little is known about direct effects of pesticides used in vineyards in South Africa on $A$. sp. near pseudococci and $C$. perminutus. A better understanding of these impacts could lead to development of strategies that reduce the disruptive effects of the pesticides in commercial vineyards.

There is a growing concern on health and environmental problems caused by heavy reliance on pesticides used against ants and mealybugs. Pesticides are used based on their efficacy and/or cost rather than their potential impacts. The presence of pesticide residues in fruit and wine results in rejection incidences on the international markets such as the USA and Taiwan (Urquart, 1999; Page, 2001) and buyer prerequisites in the UK and Western Europe outlets such as Sainsbury, Tesco, Asda and Marks and Spencer) imposing strict limits on pesticide residues. In South Africa, the scheme for Integrated Production of Wine (IPW) (http://www.ipw.co.za) has set down standard guidelines on the application and timing of pesticides to reduce the health and

*Corresponding author: e-mail: zee@sun.ac.za

Acknowledgements: This study was sponsored by Deciduous Fruit Producers Trust (DFPT), Wine Industry Network of Expertise and Technology (WineTech), and The Technology, and Human Resources for Industry Programme (THRIP). 
environmental risks associated with pesticide residues. Table 1 summarises the toxicological properties of some of the pesticides used in vineyards against ants and mealybugs.

This investigation focused on evaluating the effects of direct contact with pesticide residues on leaf tissue since parasitoids mostly come in contact with leaves during their search for mealybug hosts, feeding, mating and resting (Longley \& Jepson, 1997; Stapel et al., 2000). Topical application of pesticides on mummies containing parasitoid pupae determined the impact of ingestion of pesticide residues upon adult exit from the mummy.

The objective of these bioassays was to assess impact of pesticide residues on acute mortality of $A$. sp. near pseudococci and $C$. perminutus. This would lead to the refinement of timing of parasitoid releases to reduce pesticide-induced mortality of parasitoids in vineyards.

This investigation utilised only the egg-laying individuals for each parasitic wasp as the biocontrol effect is from females (egg laying individuals). For the arrhenotokous $A$. sp. near pseudococc $i$ only females were used and for the thelytokous $C$. perminutus, all individuals were used (Avidov et al., 1967; Islam \& Copland, 1997; Ceballo \& Walter, 2005).

\section{MATERIALS AND METHODS}

\section{Continuous exposure to residues}

Parasitoids were exposed to pesticide residues on treated glass plates for 24 hours over a range of doses and replicated five times. Exposure chambers consisted of two pesticide treated glass plates $(10 \mathrm{~cm} \times 10 \mathrm{~cm})$ fitted to a Munger cell $(10 \mathrm{~cm} \times 10 \mathrm{~cm} \times 2 \mathrm{~cm}$ internal measurements) with six holes $(0.8 \mathrm{~cm}$ diameter $)$ through the side of the walls for ventilation. The holes were covered with fine gauze using a non-toxic adhesive (Universal Silicon, Global sealants South Africa). One hole was left uncovered for introduction of parasitoids. After the introduction of parasitoids, the hole was plugged with cotton wool soaked in 50\% honeywater solution, a food source for the parasitoids. For each of five replicates, six Munger cells were assembled, (Hassan, 1992; Hassan et al., 1994) consisting of five dose rates and a blank of distilled water as a control treatment. After trial runs (range finders), $\alpha$-cypermethrin was tested from $1 / 32$ times to $1 / 2$ times

\section{TABLE 1}

Toxicological characteristics of some pesticides used in vineyards and orchards against ants and mealybugs.

\begin{tabular}{|c|c|c|c|}
\hline Pesticide & Type/Application * & Mode of action & Comment(s) \\
\hline Buprofezin & $\begin{array}{l}\text { Insect growth regulator } \\
\text { Contact/ stomach poison } \\
\text { Foliar application }\end{array}$ & $\begin{array}{l}\text { Effective against nymph stages of whitefly, scale and } \\
\text { mealybug by inhibiting chitin biosynthesis, i.e. kills } \\
\text { insect upon molting. } \\
\text { Suppresses oviposition of adults and reducing egg } \\
\text { viability (Izawa } \text { et al., 1985). }\end{array}$ & $\begin{array}{l}\text { Compatible with IPM programs utilising } \\
\text { parasitic wasps and predators such as } \\
\text { lacewings, mites, spiders except vedalia } \\
\text { beetles (James, 2004). }\end{array}$ \\
\hline Imidacloprid & $\begin{array}{l}\text { Chloro-nicotinyl } \\
\text { Systemic } \\
\text { Soil application as a drench }\end{array}$ & $\begin{array}{l}\text { Affects the nervous system by blocking the post } \\
\text { synaptic acetyl cholinesterase receptors (Stenersen } \\
\text { 2004; Buckingham et al., } 1997 \text {. }\end{array}$ & Affects beneficials that feed on nectar. \\
\hline Fipronil & $\begin{array}{l}\text { Phenyl pyrazole- chemicals with } \\
\text { herbicidal effect. } \\
\text { Contact and stomach poison and } \\
\text { moderately systemic } \\
\text { Foliar application }\end{array}$ & $\begin{array}{l}\text { Disrupts insect central nervous system via the gamma- } \\
\text { amino butyric acid (GABA) regulated chloride channel, } \\
\text { i.e. binds to the GABA receptor (Stenersen 2004; } \\
\text { Jepson 1989). }\end{array}$ & $\begin{array}{l}\text { Affects some beneficials Incompatible with } \\
\text { many IPM programs due to long residual } \\
\text { activity. }\end{array}$ \\
\hline$\alpha$-cypermethrin & $\begin{array}{l}\text { Synthetic Pyrethrin (pyrethroid) } \\
\text { Contact and stomach poison. } \\
\text { Racemic mixture of two of the } \\
\text { four cis- isomers comprising } \\
\text { cypermethrin } \\
\text { Foliar application }\end{array}$ & $\begin{array}{l}\text { Highly active broad-spectrum insecticide } \\
\text { Affects the nervous system by blocking the sodium } \\
\text { pump during nerve transmission (Stenersen 2004). }\end{array}$ & $\begin{array}{l}\text { Not compatible with many IPM programs } \\
\text { due to long residual activity. }\end{array}$ \\
\hline Mancozeb & $\begin{array}{l}\text { Ethylene bisdithio carbamate } \\
\text { (EBDC) protectant fungicide } \\
\text { Foliar application as dust or } \\
\text { wettable powder. }\end{array}$ & $\begin{array}{l}\text { Enzyme inactivation (Stenersen 2004; Jepson 1989; } \\
\text { Krieger et al., 2001). }\end{array}$ & Compatible with IPM programs \\
\hline Borax and citrus oil & $\begin{array}{l}\text { Pesticide, fungicide, miticide, } \\
\text { biorational contact pesticide. } \\
\text { Foliar application }\end{array}$ & $\begin{array}{l}\text { Biorational contact pesticide with broad spectrum control } \\
\text { of foliar pests and diseases Immediate knockdown effect. } \\
\text { Kills on contact by physically disrupting the target } \\
\text { organisms' lipid membrane rendering the organism } \\
\text { susceptible to desiccation by the environment. Effective } \\
\text { on various stages of pest (eggs, nymphs, larvae and } \\
\text { adults) (Krieger et al., 2001). }\end{array}$ & $\begin{array}{l}\text { Compatible with many IPM programs } \\
\text { because it has no documented residual } \\
\text { effect. } \\
\text { Can be mixed with pyrethroids as a } \\
\text { wetting agent or as a tank adjuvant. }\end{array}$ \\
\hline
\end{tabular}

\footnotetext{
* Anonymous 2007
} 
the recommended field dose for both parasitoids, buprofezin $1 / 4$ to four times (C. perminutus) and eight to 128 times ( $A$. sp. near pseudococci), fipronil $1 / 8$ to double (C. perminutus) and $1 / 4$ to four times (A. sp. near pseudococci) and mancozeb and the insecticidal soap, eight to 128 times for both parasitoids.

The glass plates were thoroughly cleaned with a detergent, rinsed with distilled water and then air-dried. A stock solution of the highest dose was prepared for each pesticide (depending on the range established). Serial dilutions with distilled water were then performed to give doses representing lower doses for each parasitoid species- pesticide combination as shown in Table 2.

The aqueous solutions/suspensions of pesticides were applied onto the glass plates using a standard laboratory Potter's Spray Tower (Burkhard Manufacturing Co., Ltd., Hertfordshire, UK) (Potter, 1952) with $2 \mathrm{ml}$ of each dose rate at a pressure of approximately $50 \mathrm{kPa}\left(7.25 \mathrm{lb} \mathrm{in}^{-2}\right)$ delivering approximately $0.02 \mathrm{ml}$ liquid $\mathrm{cm}^{-2}$ for each glass slide.

The spray tower was thoroughly cleaned and flushed with acetone and distilled water between treatments. Pesticides were applied in order of increasing dose rate. Each time fresh solutions/ suspensions were made, i.e. chemical solutions were not stored.

After application, the glass plates were air-dried for 10-15 min. The Munger cells were then assembled with treated glass surfaces facing inwards. Twenty parasitoids were carefully released into each cell through the uncovered hole using a special aspirator. One-day-old $C$. perminutus and one to two-day old female $A$. sp. near pseudococci were used. The Munger cells were connected to a manifold, which split the air stream to each of the six cells. To minimise pesticide vapour in the cells, the whole system was ventilated with humidified air $(70 \pm 5 \% \mathrm{RH})$ using a small aquarium pump connected to the main rubber tube. The complete system was maintained in an environment chamber at $25 \pm 0.5^{\circ} \mathrm{C}$ with a 12:12 (L: D) photoperiod.
Parasitoids were checked 6, 12, 18 and 24 hours after introduction. They were regarded as dead when they did not move (after 10 seconds) upon disturbance. A magnifying lens (OptivisorDonegan Optical Co. USA) was used to examine the parasitoids. Dose-mortality data were adjusted for control mortality using Abbott's formula (Abbott 1925) and Probit analyses performed with POLO-PC program (LeOra Software 1987) to obtain doseresponse statistics (Finney 1971; Robertson et al., 2007).

\section{Topical bioassays of field rate pesticides on parasitoid pupae}

Anagyrus species near pseudococci and C. perminutus mummies were exposed to pesticide residues to measure their susceptibility to pesticides and to investigate the role of the mummy case as a barrier to pesticides. Vine mealybugs of appropriate developmental stages were exposed to $C$. perminutus adults and fertilised females of $A$. sp. near pseudococci. After mummification, 20 mummies with each type of parasitoid were placed on a sticky tape. The tapes were placed on glass plates, which were sprayed with the recommended field dose rate for the pesticides using a standard Potter's spray tower (protocol described above). The sticky tapes were air dried for one hour then sprinkled with fine soil to prevent emerging parasitoids from coming in contact with the pesticide residues and from getting stuck on the adhesive. The tape was placed in ventilated Petri dishes (9.6 cm diameter) and kept under controlled conditions $\left(70 \pm 5 \% \mathrm{RH}, 25 \pm 0.5^{\circ} \mathrm{C}\right.$ with a $12: 12$ (L: D) photoperiod) in an environment chamber. This experiment was replicated five times for each pesticide and parasitoid species.

Parasitoid emergence was checked daily between 14:00 and 15:00 hours. Emerged parasitoids were placed in ventilated vials supplied with $50 \%$ honey-water solution. Abbott's correction formula was used to adjust for control mortality. Repeated measures ANOVA followed by Tukey's HSD test was performed in the computer program STATISTICA v.7 (Stat-Soft, South Africa) on parasitoid emergence data.

\section{TABLE 2}

Pesticides tested on Anagyrus species near pseudococci and Coccidoxenoides perminutus adults with formulations, target pests and range of doses tested.

\begin{tabular}{|c|c|c|c|c|c|}
\hline \multirow{2}{*}{$\begin{array}{l}\text { Pesticide } \\
\text { (active ingredient (a. i.)) }\end{array}$} & \multicolumn{2}{|c|}{ Formulation } & \multirow{2}{*}{ Field rate } & \multirow{2}{*}{ Target pest } & \multirow{2}{*}{$\begin{array}{l}\text { Dose rates tested } \\
(\mathrm{ml} / \mathrm{L})\end{array}$} \\
\hline & Trade name* & Grams pure a.i. & & & \\
\hline Buprofezin & $\begin{array}{l}\text { Applaud } \\
\text { SC }\end{array}$ & $400 \mathrm{~g} / \mathrm{L}$ & $\begin{array}{l}60 \mathrm{ml} / 100 \mathrm{~L} \\
(0.6 \mathrm{ml} / \mathrm{L})\end{array}$ & $\begin{array}{l}\text { Planococcus ficus } \\
\text { (Vine mealybug) }\end{array}$ & $\begin{array}{c}0.15 ; 0.3 ; 0.6 ; 1.2 ; 2.4 ; \\
4.8 ; 9.6 ; 19.2 ; 38.4 ; 76.8\end{array}$ \\
\hline$\alpha$-cypermethrin & $\begin{array}{l}\text { Fastac } \\
\text { SC }\end{array}$ & $100 \mathrm{~g} / \mathrm{L}$ & $\begin{array}{l}250 \mathrm{ml} / 100 \mathrm{~L} \\
(2.5 \mathrm{ml} / \mathrm{L})\end{array}$ & $\begin{array}{l}\text { Formicidae } \\
\text { (Ants) }\end{array}$ & $\begin{array}{c}0.0781 ; 0.1563 ; \\
0.3125 ; 0.625 ; 1.25\end{array}$ \\
\hline Fipronil & $\begin{array}{l}\text { Regent } \\
\text { SC }\end{array}$ & $200 \mathrm{~g} / \mathrm{L}$ & $\begin{array}{l}10 \mathrm{ml} / 100 \mathrm{~L} \\
(0.1 \mathrm{ml} / \mathrm{L})\end{array}$ & $\begin{array}{l}\text { Formicidae } \\
\text { (Ants) }\end{array}$ & $\begin{array}{l}0.0125 ; 0.025 ; 0.05 \\
\quad 0.1 ; 0.2 ; 0.4\end{array}$ \\
\hline Mancozeb & $\begin{array}{c}\text { Dithane M45 } \\
\text { WP }\end{array}$ & $\begin{array}{c}800 \mathrm{~g} / \mathrm{kg} \\
(80 \%)\end{array}$ & $\begin{array}{l}200 \mathrm{~g} / 100 \mathrm{~L} \\
(2 \mathrm{~g} / \mathrm{L})\end{array}$ & $\begin{array}{l}\text { Plasmopara viticola } \\
\text { (Downy mildew) }\end{array}$ & $\begin{array}{l}16 ; 32 ; 64 \\
128 ; 256\end{array}$ \\
\hline $\begin{array}{l}\text { Insecticidal soap } \\
\text { (borax and orange oil) }\end{array}$ & $\begin{array}{l}\text { Wet-Cit } \\
\text { EC }\end{array}$ & $\begin{array}{c}\text { Borax } 10 \mathrm{~g} / \mathrm{kg} \\
\text { Orange oil } 50 \mathrm{~g} / \mathrm{kg}\end{array}$ & $\begin{array}{l}50 \mathrm{ml} / 100 \mathrm{~L} \\
(0.5 \mathrm{ml} / \mathrm{L})\end{array}$ & $\begin{array}{l}\text { Planococcus ficus } \\
\text { (Vine mealybug) }\end{array}$ & $4 ; 8 ; 16 ; 32 ; 64$ \\
\hline
\end{tabular}

$* \mathrm{SC}=$ soluble concentrate; $\mathrm{WP}=$ Wettable power; $\mathrm{EC}=$ Emulsifiable concentrate. 
TABLE 3

Probit parameters of dose responses of Anagyrus sp. near pseudococci to various doses of different pesticide residues during a 24-hour bioassay.

\begin{tabular}{|c|c|c|c|c|c|c|}
\hline Pesticide & $\begin{array}{l}\text { Field dose rate } \\
\qquad(\mathrm{ml} / \mathrm{L})\end{array}$ & $\begin{array}{c}\chi^{2} \\
\text { (d.f) }\end{array}$ & $\begin{array}{c}\mathrm{LC}_{50} \\
(\mathrm{ml} / \mathrm{L})\end{array}$ & $\begin{array}{l}95 \% \text { fiducial } \\
\text { limits }\end{array}$ & $\begin{array}{c}\mathbf{L C}_{90} \\
(\mathrm{ml} / \mathbf{L})\end{array}$ & $95 \%$ fiducial limits \\
\hline$\alpha$-cypermethrin & 2.5 & $\begin{array}{c}1.79 \\
(3)\end{array}$ & 0.25 & 0.187 to 0.317 & 3.28 & 1.95 to 7.57 \\
\hline Fipronil & 0.1 & $\begin{array}{c}0.92 \\
(3)\end{array}$ & 0.15 & 0.138 to 0.169 & 0.344 & 0.3 to 0.41 \\
\hline Buprofezin & 0.6 & $\begin{array}{c}8.94 \\
(3)\end{array}$ & 31.8 & 19.29 to 54.16 & 126 & 68.13 to 753 \\
\hline Mancozeb* & 2 & $\begin{array}{c}2.76 \\
(3)\end{array}$ & - & - & - & - \\
\hline Insecticidal soap & 0.5 & $\begin{array}{c}0 \\
(3)\end{array}$ & - & - & - & - \\
\hline
\end{tabular}

*LC values of Mancozeb and insecticidal soap were not established for $A$. sp. near pseudococci

\section{TABLE 4}

Probit parameters of dose responses of Coccidoxenoides perminutus to various doses of different pesticides residues during a 24-hour bioassay.

\begin{tabular}{|c|c|c|c|c|c|c|}
\hline Pesticide & $\begin{array}{l}\text { Field dose rate } \\
\qquad(\mathrm{ml} / \mathrm{L})\end{array}$ & $\begin{array}{c}\chi^{2} \\
\text { (d.f) }\end{array}$ & $\begin{array}{c}\mathrm{LC}_{50} \\
(\mathrm{ml} / \mathrm{L})\end{array}$ & $\begin{array}{l}95 \% \text { fiducial } \\
\text { limits }\end{array}$ & $\begin{array}{c}\mathbf{L C}_{90} \\
(\mathbf{m l} / \mathbf{L})\end{array}$ & $95 \%$ fiducial limits \\
\hline$\alpha$-cypermethrin & 2.5 & $\begin{array}{l}0.96 \\
(2)\end{array}$ & 0.19 & 0.154 to 0.227 & 0.96 & 0.744 to 1.345 \\
\hline Fipronil & 0.1 & $\begin{array}{c}10.91 \\
(3)\end{array}$ & 0.026 & 0.014 to 0.039 & 0.083 & 0.052 to 0.254 \\
\hline Buprofezin & 0.6 & $\begin{array}{c}2.43 \\
(3)\end{array}$ & 2.59 & 2.08 to 3.78 & 10.11 & 5.92 to 32.92 \\
\hline Mancozeb & 2 & $\begin{array}{c}0.56 \\
(3)\end{array}$ & 86.78 & 66.1 to 116.5 & 1217.15 & 646.9 to 3492.2 \\
\hline Insecticidal soap & 0.5 & $\begin{array}{l}6.06 \\
(3)\end{array}$ & 29.57 & 19.5 to 44.97 & 106.8 & 63.29 to 410.5 \\
\hline
\end{tabular}

\section{RESULTS}

\section{Continuous exposure to pesticide residues}

Population responses to pesticides for $A$. sp. near pseudococci and C. perminutus were significantly different since none of the $95 \%$ fiducial limits overlapped for the two parasitoid species (Tables 3 and 4) (Robertson et al., 2007).

For $A$. sp. near pseudococci, the $\mathrm{LC}_{50}$ value for fipronil was 1.5 times larger than the field dose rate. However, fipronil is one of the most persistent pesticides making it toxic to parasitoids over a long period of time (Stenersen, 2004). $\alpha$-cypermethrin LC $_{50}$ was 10 times lower than the field dose rate for the same parasitoid. Although $\mathrm{LC}_{50}$ and $\mathrm{LC}_{90}$ values for Mancozeb and insecticidal soap were estimated for $A$. sp. near pseudococci, no estimates of the $95 \%$ fiducial limits could be made and therefore not given (Table 3) implying that there was no correlation between dose rate and mortality for these two pesticides.
For $C$. perminutus, the field dose rates were higher than the $\mathrm{LC}_{50}$ values for $\alpha$-cypermethrin and fipronil by 13 times and five times, respectively. These results indicate that these two pesticides were the most toxic of those tested on $A$. sp. near pseudococci and C. perminutus. The hypotheses of equality $\left(\chi_{\mathrm{df}=2}^{2}=17.4813\right.$ and $\chi_{\mathrm{df}=2}^{2}=365.7 ; \mathrm{p} \leq 0$, respectively) and parallelism $\left(\chi_{\mathrm{df}=1}^{2}=9.3027\right.$; $\mathrm{p}=0.002$ and $\chi_{\mathrm{df}=1}^{2}=10.4753 ; \mathrm{p}=0.001$, respectively) of probit regression lines for $\alpha$ - cypermethrin and fipronil were rejected.

Buprofezin, mancozeb and the insecticidal soap were not toxic to parasitoids within their recommended field rates although at high doses $C$. perminutus was more affected by these pesticides compared to $A$. sp. near pseudococci). For buprofezin, mancozeb and the insecticidal soap, the hypothesis that probit regression lines were equal was rejected $\left(\chi_{\mathrm{df}=2}^{2}=123.6,340.28\right.$ and 196.28, respectively; $\mathrm{p} \leq 0$ in all cases) while that of parallelism was accepted $\left(\chi_{\mathrm{df}=1}^{2}=0.021 ; \mathrm{p}=0.963, \chi_{\mathrm{df}=1}^{2}=0.2965 ; \mathrm{p}=0.586\right.$ and $\chi_{\mathrm{df}=1}^{2}$ $=3.0392 ; \mathrm{p}=0.081$, respectively). 
TABLE 5

The mean number of days to emergence and number of emerged parasitoids after topical pesticide treatments of 10 day old mummies $(n=20)$.

\begin{tabular}{|c|c|c|c|c|}
\hline \multirow{2}{*}{ Pesticide Treatment } & \multicolumn{2}{|c|}{ A. sp. near pseudococci } & \multicolumn{2}{|c|}{ C. perminutus } \\
\hline & Days to emerge $^{\dagger}$ & Emerged & Days to emerge $^{\dagger}$ & Emerged \\
\hline Water & $\begin{array}{c}7.1^{\mathrm{a}} \\
(0.33)\end{array}$ & $\begin{array}{c}14.4 \\
(0.20)\end{array}$ & $\begin{array}{c}5.2^{\mathrm{a}} \\
(0.21)\end{array}$ & $\begin{array}{c}16.5 \\
(0.23)\end{array}$ \\
\hline$\alpha$-cypermethrin & $\begin{array}{c}5.5^{\mathrm{a}} \\
(0.09)\end{array}$ & $\begin{array}{c}12.5 \\
(0.25)\end{array}$ & $\begin{array}{c}6.0^{\mathrm{a}} \\
(0.11)\end{array}$ & $\begin{array}{c}15.1 \\
(0.93)\end{array}$ \\
\hline Buprofezin & $\begin{array}{c}12.7^{\mathrm{b}} \\
(0.23)\end{array}$ & $\begin{array}{c}14.1 \\
(0.20)\end{array}$ & $\begin{array}{c}11.8^{\mathrm{b}} \\
(0.28)\end{array}$ & $\begin{array}{c}15.7 \\
(0.51)\end{array}$ \\
\hline Fipronil & $\begin{array}{c}7.5^{\mathrm{a}} \\
(0.12)\end{array}$ & $\begin{array}{c}12.5 \\
(0.40)\end{array}$ & $\begin{array}{c}5.4^{\mathrm{a}} \\
(0.15)\end{array}$ & $\begin{array}{c}14.5 \\
(0.60)\end{array}$ \\
\hline Mancozeb & $\begin{array}{c}7.1^{\mathrm{a}} \\
(0.52)\end{array}$ & $\begin{array}{l}14.1 \\
(0.4)\end{array}$ & $\begin{array}{c}6.2^{\mathrm{a}} \\
(0.66)\end{array}$ & $\begin{array}{c}15.1 \\
(0.25)\end{array}$ \\
\hline Insecticidal soap & $\begin{array}{c}6.3^{\mathrm{a}} \\
(0.53)\end{array}$ & $\begin{array}{c}13.6 \\
(0.33)\end{array}$ & $\begin{array}{c}7.0^{\mathrm{a}} \\
(0.46)\end{array}$ & $\begin{array}{c}14.9 \\
(0.44)\end{array}$ \\
\hline
\end{tabular}

$\dagger$ Means in columns with different letters denote significant difference at $95 \%$ confidence limits.

$\pm \mathrm{SE}$ in parenthesis.

\section{Topical application of field rate pesticides on parasitoid pupae}

Days to parasitoid emergence after treatment with pesticides significantly differed between treatments $\left(\mathrm{F}_{(5,24)}=24.48 ; \mathrm{p} \leq\right.$ $0.001)$ with buprofezin causing a significant delay in emergence by almost a week relative to other treatments (Table 5 ). Days to emergence did not differ significantly between species $\left(\mathrm{F}_{(1,58)}=\right.$ $1.02 ; \mathrm{p}=0.3167)$.

Significantly, more $C$. perminutus emerged than $A$. sp. near pseudococci $\left(\mathrm{F}_{(10,46)}=6.514 ; \mathrm{p} \leq 0.001\right)$. No significant differences were found between treatments for C. perminutus $\left(\mathrm{F}_{(5,24)}=0.6842\right.$; $\mathrm{p}=0.6399)$. A. sp. near pseudococci mortality due to fipronil and $\alpha$-cypermethrin was significantly higher than the other treatments $\left(\mathrm{F}_{(5.24)}=19.604 ; \mathrm{p} \leq 0.05\right)$.

\section{DISCUSSION AND CONCLUSION}

Mortality rates due to insecticide residues on glass plates in cells provide an indication of impact of pesticide residues on parasitoids. However, the field situation with pesticide residues on vine foliage is likely to be lower. Longley \& Jepson (1997) indicated a difference in bioavailability due to pesticide residues becoming bound with the epicuticular layers on leaf surfaces, amongst other factors. The toxicity calculations obtained in this investigation pertain to glass plates as substrates and may therefore differ from results obtained using natural substrates such as leaves. Additionally, insects in the field can shelter in places where pesticide residues may not reach them, for example, parasitised vine mealybug can hide under the bark or crevices subsequently protecting the developing parasitoids. Results may also vary due to insect generation, sex, species and size of parasitoids.

Fipronil is used to control ants in vineyards. Control of ants in mealybug-infested vineyards allows $A$. sp. near pseudococci access to mealybug that they would not otherwise access in the presence of ants. Mgocheki and Addison (2009) demonstrated that the main ant species present in Western Cape vineyards significantly affects this parasitoid.

$\alpha$-cypermethrin and fipronil caused high mortality of the parasitoids, therefore, may not be compatible with IPM programs utilising parasitoids for vine mealybug control, unless these pesticides are used in containerised low toxic baits, or applied to an area of the vine not utilised by parasitoids, such as the stem. Walton and Pringle (1999) also found cypermethrin to be very toxic to C. perminutus and discouraged full cover application of this pesticide during augmentative release periods.

Observations showed that $A$. sp. near pseudococci died as they gnawed an exit hole with their mandibles through the dorsal portions of the mummies treated with fipronil and $\alpha$-cypermethrin. The resulting partial emergence indicated the high degree of toxicity of these two pesticides. Chewing an exit hole presented a risk for parasitoids ingesting the pesticides, which are stomach poisons. In the field, $A$. sp. near pseudococci could be poisoned by feeding on contaminated mealybug honeydew, an important food source for parasitoids. Consequently, parasitoid mortality could result or their performance adversely affected (Wang et al., 2008). Mortality of parasitoids at the time of emergence has been documented for adults of aphid parasitoids (Hsieh \& Allen, 1986; Krespi et al., 1991; Lingren et al., 1991; Islam \& Copland, 1997; Walton \& Pringle, 1999). Low mortality of $C$. perminutus when exposed to fipronil and $\alpha$-cypermethrin could be due to a different mechanism of exiting the mummy case. They push to crack open the mummy case instead of chewing an exit hole subsequently avoiding ingestion of poison. Mortality rates were low across treatments indicating that the mummy case is indeed, an efficient barrier to pesticides. From this investigation, the adult stage of parasitoid was more vulnerable to pesticides than the juvenile stages developing in the mummies. 
Timing of insecticide application is very crucial given the continued conventional high volume spraying in commercial vineyards. The use of economic injury levels (EIL) and economic thresholds (ET) for pests pays no regard to the role of natural enemies, therefore some adaptations to population dynamics of important parasitoid species is required. Pesticide treatments can be restricted to periods of low activity of the vulnerable stages of parasitoids (adults), for example, early spring treatments. The limited persistence of active ingredients such as $\alpha$-cypermethrin may be exploited to achieve selectivity (Elzen, 1989). If only the insensitive stages of parasitoids within mummified mealybugs are exposed to treatment, the more sensitive adults may be protected (Metcalfe, 1980). Stem application of pesticides in hot spots later in the season minimises risk to parasitoids, which by this time will have a large prey population to achieve maximum parasitism rates, and provides areas where parasitoids can shelter.

Although buprofezin and the insecticidal soap showed little negative impact on parasitoids in the laboratory, in vineyards, these two pesticides can reduce populations of parasitoids indirectly by reducing populations of VMB (Grafton-Cardwell et al., 2006). In South Africa, the use of buprofezin has been warned against especially when utilising coccinellid predators as main natural enemies for mealybugs and cottony cushion scale (Hattingh \& Tate, 1995). Exposure of mealybug mummies containing parasitoid pupae to buprofezin showed a delayed emergence of adults. This may interfere with the phenological synchrony between mealybugs and their parasitoids resulting in reduced ability of the parasitoids to regulate mealybug populations. The reproductive statistics of $A$. pseudococci (Güleç et al., 2007) and C. perminutus (Davies et al., 2004) suggest that these biological control agents will be able to complete more generations than the mealybug within the field temperatures, thus, they are both effective against $P$. ficus where pesticides are used selectively.

$\alpha$-cypermethrin and fipronil were very toxic vineyard pesticides to mealybug parasitoids while buprofezin, mancozeb and insecticidal soap did not cause any significant mortality at the recommended field rates. $A$. sp. near pseudococci adults were more robust and resilient to pesticides than C. perminutus, possibly due to their larger size. Although the insecticidal soap and buprofezin caused no significant parasitoid mortality, they can impact on parasitoids indirectly by reducing the host (mealybugs) population. Timing of pesticide application is very important regarding the vulnerable stages of parasitoids. C. perminutus are released as pupae while $A$. sp. near pseudococci are released as adults. This affects the choice of parasitoid and timing of augmentative release regarding breakdown of pesticides on plant surfaces.

\section{LITERATURE CITED}

Abbott, W.S., 1925. A method of computing the effectiveness of an insecticide. J. Econ. Entomol. 18, 265-267.

Anonymous, 2007. A Guide for the Control of Plant Pests. Directorate: Food Safety and Quality Assurance; Subdirectorate: Agricultural Production Inputs. 40th Ed. Department of Agriculture, Republic of South Africa Government Printer, Pretoria.

Avidov, Z., Rössler, Y. \& Rosen, D., 1967. Studies on an Israel strain of Anagyrus pseudococci (Girault) (Hymenoptera: Encyrtidae). II. Some biological aspects, Biocontrol 12, 111-118.
Buckingham, S.D., Lapied, B., Le Corronc, H., Grolleau, F. \& Sattelle, D.B., 1997. Imidacloprid actions on insect neuronal acetylcholine receptors. J. Exp. Biol. 200, 2685-2692.

Ceballo, F.A. \& Walter, G.H., 2005. Why is Coccidoxenoides perminutus, a mealybug parasitoid, ineffective as a biocontrol agent - Inaccurate measures of parasitism or low adult survival? Biol. Control 33, 260-268.

Davies, A. P., Ceballo, F. A. \& Walter, G. H., 2004. Is the potential of Coccidoxenoides perminutus, a mealybug parasitoid, limited by climatic or nutritional factors? Biol. Control 31, 181-188.

Desneux, N., Decourtye, A. \& Delpeuch, J.M., 2007. The sublethal effects of pesticides on beneficial arthropods. Ann. Rev. Entomol. 52, 81-106.

Elzen, G.W., 1989. Sublethal effects of pesticides on beneficial parasitoids. In: Jepson, P.C. (ed). Pesticides and non-target invertebrates. Intercept Dorset, UK, pp129-150.

Finney, D.J., 1971. (3rd ed) Probit Analysis, Cambridge University Press, Cambridge, UK.

Grafton-Cardwell, E.E., Lee, J.E., Stewart, J.R. \& Olsen, K.D., 2006. Role of two insect growth regulators in Integrated Pest Management of citrus scales. J. Econ. Entomol. 99, 733-744.

Güleç, G., Kilinçer, A., Kaydan, M. \& Ülgentürk, S., 2007. Some biological interactions between the parasitoid Anagyrus pseudococci (Girault) (Hymenoptera: Encyrtidae) and its host Planococcus ficus (Signoret) (Hemiptera: Coccoidea: Pseudococcidae). J. Pest Sci. 80, 43-49.

Hassan, S.A., 1992. Guidelines for testing the effects of pesticides on beneficial organisms: Description of test methods. Int. Org. Biol. Control Bulletin (IOBC) 15 .

Hassan, S.A., Bigler, F., Bogenschütz, H., Boller, E., Brun, J.N.M., CoremansPelseneer, J., Duso, C., Grove, A., Heimbach, U., Helyer, N., Hokkanen, H., Lewis, G.B., Mansour, F., Moreth, L., Samsøe-Petersen, L., Sauphanor, B., Stübli, A., Sterk, G., Vainio, A., Veire, M., Van de Viggiani, G. \& Vogt, H., 1994. Results of the sixth joint pesticide testing programme on the IOBC/WPRS- working group 'Pesticides and beneficial organisms'. Entomophaga 30, 107-119.

Hattingh, V. \& Tate, B., 1995. Effects of field-weathered residues of insect growth regulators on some Coccinellidae (Coleoptera) of economic importance as biocontrol agents. Bulletin of Entomol. Res. 85, 489-493.

Heunis, J.M. \& Pringle, K.L., 2003. The susceptibility of Aphenilus mali (Haldeman), a parasitoid of Eriosoma lanigerum (Hausmann), to pesticides used in apple orchards in the Elgin area, Western Cape Province, South Africa. African Entomol. 11, 91-95.

Hsieh, C.Y. \& Allen, W.W., 1986 Effects of insecticides on the emergence, survival, longevity and fecundity of the parasitoid Diaeretiella rapae (Hymenoptera: Aphidiidae) from mummified Myzus persicae (Homoptera: Aphididae). J. Econ. Entomol. 79, 1599-1602.

Islam, K.S. \& Copland, M.J.W., 1997. Host preference and progeny sex ratio in a solitary koinobiont mealybug endoparasitoids, Anagyrus pseudococci (Girault) in response to its host stage. Biocontrol Sci. Technol. 7, 449-56.

Izawa, Y., Uchida, M., Sugimoto, T. \& Asai, T., 1985. Inhibition of chitin biosynthesis by buprofezin analogs in relation to their activity controlling Nilapavata lugens Stal. Pesticide Biochem. Physiol. 24, 343-347.

James, D.G., 2004. Effect of Buprofezin on Survival of Immature Stages of Harmonia axyridis, Stethorus punctum picipes (Coleoptera: Coccinellidae), Orius tristicolor (Hemiptera: Anthocoridae), and Geocoris spp. (Hemiptera: Geocoridae). J. Econ. Entomol. 97, 900-904.

Jepson, P.C., 1985. The temporal and spatial dynamics of pesticide side-effects on non-target invertebrates. In: Jepson, P.C., (ed). Pesticides and non-target invertebrates, Edited by Intercept, Dorset, UK, pp. 95-144.

Krespi, L., Rabasse, J.M., Dedryver, C.A. \& Nenon, J.P., 1991. Effect of three insecticides on the life cycle of Aphidius uzbekistanicus Luz. (Hymenoptera: Aphidiidae). J. Appl. Entomol. 111, 113-119.

Krieger, R., Doull, J., Ecobichon, D., Gammon, D., Hodgson, E., Reiter, L. \& Ross, J., 2001 (2nd ed) Handbook of Pesticide Toxicology. Principles Volume 2. Academic Press.

Lingren, P.D., Wolfenbarger, D.A., Nosky, J.B. \& Diaz, M. Jr., 1991. Response of Campoletis perdistinctus and Apanteles marginiventris to insecticides. J. Econ. Entomol. 65, 1295-1299. 
Longley, M. \& Jepson, P., 1997. Effects of life stage, substrate and crop position on the exposure and susceptibility of Aphidius rhopalosiphi Destefani-Perez (Hymenoptera: Braconidae) to deltamethrin. Environ. Toxicol. Chem. 16, 10341041

Metcalf, R.L., 1980. Changing role of insecticides in crop protection. Ann. Rev. Entomol. 25, 219-256.

Mgocheki, N. \& Addison, P., 2009. Interference of ants (Hymenoptera: Formicidae) with biological control of the vine mealybug Planococcus ficus (Signoret) (Hemiptera: Pseudococcidae). Biol. Control 49, 180-185.

Page, H., 2001. South Africa Competitor Report Horticultural Products. USDA Foreign Agricultural Service.

Potter, C., 1952. An improved laboratory apparatus for applying direct sprays and surface films, with data on the electrostatic charge on atomized spray fluids. Ann. Appl. Biol. 110, 441-454.

Robertson, J.L., Preisler, H.K., Russel, R.M. \& Savin, N.E., 2007. (2nd ed) Bioassays with Arthropods. CRC Press Taylor and Francis Group. London, pp. 21-31.

St. Leger Searle, C.M., 1963. An investigation into the problem of integrated biological and chemical control of citrus pests with special reference to the effect of insecticides on a parasite (Pauridia peregrine Timb) and a predator (Exochomus flavipes Thunb.). MSc. Thesis. University of Pretoria, Pretoria, South Africa.

Stapel, J.O., Cortesero, A.M. \& Lewis, W.J., 2000. Disruptive sublethal effects on biological control: Altered foraging ability and life span of a parasitoid after feeding on extra floral nectar of cotton treated with systemic insecticides. Biol. Control 17, 243-249.
Stenersen, J., 2004. Chemical pesticides. Mode of action and toxicology. CRC Press. New York.

Urquhart, P., 1999. IPM and the citrus industry in South Africa. Gatekeeper Series, Number SA86.

Wakgari, W. \& Giliomee, J., 2001 Effects of some novel insecticides and insect growth regulators on different phenological stages of the white wax scale, Ceroplastes destructor Newstead (Hemiptera: Coccidae) and its primary parasitoid Aprostocetus ceroplastae Girault. Hymenoptera: Eulophidae). Int. J. Pest Management 47, 179-184

Walton, V.M. \& Pringle, K.L., 1999. Effects of pesticides used on table grapes on the mealybug parasitoid Coccidoxenoides peregrinus (Timberlake) (Hymenoptera: Encyrtidae). S. Afr. J. Enol. Vitic. 20, 31-34

Wang, H.Y., Yang, Y., Su, J.Y., Shen, J.L., Gao, C.F. \& Zhu, Y.C., 2008. Assessment of the impact of insecticides on Anagrus nilaparvatae (Hymenoptera: Mymanidae), an egg parasitoid of the rice planthopper, Nilaparvata lugens (Hemiptera: Delphacidae). Crop Protection 27, 514-522.

Williams III, L. \& Price, L.D., 2004. A space- efficient contact toxicity bioassay for minute Hymenoptera, used to test the effects of novel and conventional insecticides on the egg parasitoids Anaphes iole and Trichogramma pretiosum. Biocontrol 49, 163-185.

Whitehead, V.B., 1957. A study of the predators and parasites of Planococcus citri, Risso (Homoptera: Pseudococcidae) on vines in the Western Cape Province, South Africa. MSc. Thesis. Rhodes University, Grahamstown. 